\title{
Some Comments on Recent Developments in the Indonesian Marriage Law with Particular Respect to the Rights of Women
}

\author{
By S. Pompe and J.M.Otto
}

\section{Introduction}

Indonesia is known to be the country with the largest Muslim population in the world. A minority of perhaps only $10 \%$ is non-Muslim. 1 Within the many-sided Indonesian culture, not all Indonesian Muslims adhere strictly to the faith: the larger portion are the so-called "Muslim statistik" as opposed to the "Muslim fanatik" minority. Yet one of the compelling legal questions concems the place and role of Islamic religious prescripts in the Indonesian formal legal system. With the recent so-called Islamic revival, this question has become if anything even more important.

One complicating factor is that Islamic religious prescripts in Indonesia have to compete with normative systems that are remarkably well established, notably the customary law ("adat law"). Besides state law, Indonesians are in many cases governed in their private lives by both Islamic religious prescripts and by their customs. Thus one of the areas which is commonly regarded as very Islamicized, the Minangkabau, still has a customary matrilineal inheritance system regarding real property.

In colonial times indigenous norms had by and large been regarded as basically Islamic until the second half of the nineteenth century. 2 From that time the role of customary law was progressively emphasized and stregthened at the expense particularly of Islam. Thus, whilst initially it was held that Islamic religious prescripts should be applied to Muslims under all circumstances, the view took hold by the end of the nineteenth century that this should only be so to the extent society had accepted it through its customary law. 3 The former position is reflected in the colonial code on the religious courts which applied until December 19894 , when it was eventually replaced.5 The latter view, rather confusingly

1 D. Noer, Contemporary political dimensions of Islam, in: MB. Hooker, Islam in South East Asia, Leiden: Brill, 1983, p. 184.

2 C. van Vollenhoven, De ontdekking van het adatrecht, Leiden: Brill, 1928.

3 D.S. Lev, Islamic Courts in Indonesia, Los Angeles: University of Califomia Press, 1972, p. 8.

4 Regulation on the Priestcourts in Java and Madura (Wet op de Priesterraden), S. 1882-152 jo. 153. It was drafted by L.W.C. van den Berg. The reference codes for Indonesian legislation and jurisprudence are not always systematically identical. We have cited them as they appeared in the books. The jurisprudence is available at the Van Vollenhoven Institute. 
called the "reception theory", was supported by Snouck Hurgronje, who eventually prevailed. The reception theory was eventually incorporated in the colonial constitution. 6 The result was that "Islam had no place of its own in the N.E.I. plural law system".7

In these days, the reception theory has been called satanic by prominent Islamic scholars in Indonesia. 8 Yet it is not evident that it has been entirely abandoned by the state. 9 Religious prescripts are not constitutionally recognized as a formal source of law, even though belief in one God is part of the state ideology embodied in the 1945 Constitution.10 Also, religious prescripts have seldom influenced Indonesian legislation. Thus, of the three fields of law arguably most closely associated with Islamic religious prescripts, family law, penal law and the usury prohibition, only the first is reflected in Indonesian legislation. It is to this field that this paper will turn.

Islamic family law generally and marriage in particular have of course attracted the attention of quite a few authors 11 and in any case they figure prominently in most studies on Islamic religious prescripts. In spite of the universality of the Islamic creed, legislators in the various countries of the Muslim world have not taken an identical stance on the subject.

5 Law nr. 7/1989 on the Religious Courts.

6 It was embodied in art. 134 (2) of the colonial constitution, the "Indische Staatsregeling", S. 18542 in 1925. C. Snouck Hurgronje, Mr. L.W.C. van den Berg's beoefening van het Mohammedaansche recht, De Indische Gids, 1884, p. 363-434, 737-816. Snouck did not of course win on all fronts, $H J$. Benda, The crescent and the rising sun, The Hague: van Hoeve, 1958.

$7 M B$. Hooker, Muhammedan Law and Islamic Law, in: MB. Hooker (Ed.), Islam in South-East Asia, Leiden: Brill, 1983, p. 178.

8 Hazairin, Tinjauan mengenai U. U. Perkawinan nomor $1 / 1974$ dan lampiran U. U. nomor 1/1974, Jakarta: Tintamas, 1975, repeated recently in a speech by the Supreme Court judge B. Siregar, Pengembangan hukum Islam dan penerapannya dalam hukum nasional, Varia Peradilan III/36, 1988 , p. 146-155.

9 One crucial difference it must be admitted in this respect between the colonial and the present legal systems arguably lies in the role of customary law as a vehicle to Islamic religious prescripts. Whereas in colonial times custom was, within certain limits, accepted as a source of law, this is not evidently so after independence. On the basis of art. 2 of the Marriage Law nr. 1/1974, it is possible to argue that Islam has now become a source of law in its own right (as indeed argued by M B. Hooker, Islamic Law in South-East Asia, Singapore: Oxford University Press, 1984, p. 273, and surplanted customary law. Yet so far, only marriage law and to a lesser extent inheritance appear to have been affected.

10 The Indonesian government is of ten at pains to emphasize that Indonesia is not a secular state, as illustrated with the speech of the Indonesian President at the General Meeting of the People's Congress in 1988. (H. Ichtiyanto, Perkawinan campuran menurut undang - undang Perkawinan, Hukum dan Pembangunan 2, 1989, p. 123.)

11 G.H.A. Juynboll, Frauenemanzipation und moderne Gesetzgebung im Nahen Osten - einige Betrachtungen, in: A. Mercier (Hrsg.), Islam und Abendland. Geschichte und Gegenwart, Bem: Peter Lang, 1976, and the publications cited in the biography L. Beck and N. Keddie, Women in the Muslim World, Cambridge Mass.: Harvard University Press, 1978. 
Taking polygamy as an example, in some countries polygamy has been banned by the legislator, in Tunesia with explicit reference to the Koran and in Turkey by purporting to break with it. In those countries where it has been accepted by the law, the conditions vary greatly. 12

This paper proposes to consider the way Islamic religious prescripts on marriage are couched in modem Indonesian legislation. Particular attention will be paid to the rights of Muslim women in marriage. It is divided in three parts. The first will consider the importance of the Indonesian Marriage Law of 1974 in Indonesian legal development. The second will consider the law with respect to polygamy and unilateral divorce. This will be compared briefly with religious prescripts in these matters. The third will consider some aspects of effectiveness as reflected in the academic literature and the official statistics. 13

\section{Three Basic Points of Reform}

The Indonesian Marriage Law of 1974 is one of the best-known pieces of Indonesian legislation.14 An important reason for its instant fame is that it is fundamentally innovative in legal terms. The innovation regards essentially three points which the government aimed to reform. These are closely interconnected.

The first innovation in this law ist that it purports to bring the pluralistic system of marriage to an end. 15 This system had been inherited from colonial times and had been by and large maintained in Indonesia up to 1974. It distinguished between three population groups, each having its own law. The new law aims at creating legislation that applies equally to all Indonesians. 16

12 Juynboll, s. footnote 11; JL. Nasir, The Islamic Law of Personal Status, London: Graham \& Trotman, 1986, p. 60.

13 This paper looks at the subject from the perspective of Indonesian state law. This is a matter of definition and does not deny the existence or importance of other normative systems. Unless stated otherwise, with law is meant Indonesian state law therefore, unregulated refers to unregulated by Indonesian state law and the intention of the legislator as that which can be gleaned from official Indonesian govemment sources.

14 Together with the Constitution of 1945 of course and the Basic Agrarian Act nr. 1/1960.

15 According to the official sources, this was the principal consideration for enacting this law. The heading of the law itself mentions as sole reason for its creation that "a single law on marriage is needed which applies to all nationals" in accordance with the Pancasila doctrine (Lembaran Negara Republik Indonesia 1974, p. 1). The applying to all population groups as another principal consideration (Tambahan Lembaran Negara Republik Indonesia 1974, p. 1).

16 This legislative policy has been the principal basis of legal development in Indonesian private law after 1945. Gouwgioksiong, De rechtsontwikkeling in Indonesië na de souvereiniteitsoverdracht, 
The second innovation regards the legal foundation of marriage. In effecting the unification, the Marriage Law breaks with the legal system prevailing to that date and which provided essentially for civil marriages. 17 Instead, the famous art. 2 of the Marriage Law points to religion as the prime point of reference for marriage. 18 It says that marriage must be concluded in accordance with the religions and beliefs of both parties. 19 The Indonesian Supreme Court has recently held the religious basis of marriage to be so fundamental, that colonial regulations based on the civil marriage system must be deemed to be null and void even if there is no new legislation to replace them. 20

WPNR 1968, 4982-4984, p. 61-63, 89-91, 101-104, and De verhouding tussen intemationaal privaatrecht en intergentiel recht in Indonesië, NTIR 1968, XIV, p. 345-366.

17 The Marriage Law mentions the creation of a happy family first. The official elucidation indicates that what is meant by this is a duty of care of the partners in marriage, both towards each other and towards their children. This cannot be regarded as fundamentally innovative: Art. 103 and 104 of the Dutch colonial Civil Code and art. 81 and 82 of the present Dutch Civil Code state the same. That religion is the prime reference point of marriage is mentioned as the next most important characteristic of marriage (Tambahan Lembaran Negara Republik Indonesia 1974, p. 2, point 4 sub b). It must be pointed out that marriages between Indonesian Muslims, constituting the large majority of the population of course, had remained largely unregulated up to 1974 with certain exceptions, such as the procedure for marital disputes (Royal Decree nr. 24/1882, S. 1882-152 jo. 153) or registration requirements (Law nr. 22/1954). These marriages were then in fact often not concluded in accordance with Islamic prescripts. The break with the past in 1974 lies in the fact that state law, having hitherto explicitly recognized civil marriages only, now states categorically that marriage must be based on religion.

18 It has been argued that on the basis of this article the colonial reception theory has been abandoned (Hazairin, see footnote 8; Jafizham, Persintuhan Hukum di Indonesia dengan Hukum Perkawinan Islam, Medan: Mestika, 1977). On the practical problems in which too dogmatic an approach may result in the field of inheritance see recently A. Kohar, Menemukan titik kaitan Waris Hukum Adat dengan Hukum Islam, Yuridika (majalah fakultas hukum Universitas Airlangga) 1988, 8/III, Perbruari-Maret, p. 18-25. The new law on the religious courts definitely includes inheritance in the competence of the religious courts, inasfar as based on Islamic law (art. 49 (1) (b)). See also: $S$. Thalib, Pengadilan Agama, Hukum dan Pembangunan 2, 1989, p. 114-122, 121.

19 Art. 2 (1): Perkawinan adalah sah, apabila dilakukan menurut hukum masing-masing agamanya dan kepercayaannya itu. This can be translated as follows: A marriage is valid, if it is concluded in accordance with the religion and belief of both parties.

20 Decision of the Mahkamah Agung nr. $1400 \mathrm{~K} / \mathrm{Pdt} / 1986$, dated 20 January 1989, in: Varia Peradilan IV/45, June 1989, p. 73-86. See also the weekly journal Tempo, 24 June 1989. Inasfar as relevant here, the decision can be briefly summarized as follows. First, the Marriage Law of 1974 does not provide for marriages between partners of different religions. Second, by virtue of transitory art. 66 of this law the colonial Regulation on Mixed Marriages (Regeling op de Gemengde Huwelijken S. 1898-158) goveming these marriages would appear to apply. Third, this ist not so, as this regulation is based on the system of civil marriages, which has now been abandoned in Indonesia. Other colonial regulations explicitly voided in this judgment are the Civil Code inasmuch as relevant here (meaning presumably book 1 ) and the regulation on marriages between Christian Indonesians (Huwelijksordonnantie Christen Indonesiëers S. 1922-74). See also the rather spectacular case note of $B$. Siregar, Benarkah perkawinan beda agama recht vacuum?, Varia 
The third innovation regards the rights of women in marriage. For a long time (Muslim) women activists in Indonesia have wanted to assure women in marriage of better rights. 21 The Marriage Law proposes to answer this wish. Whereas in the Marriage Law this protection applies to all women, it is clear that in particular women in Muslim marriages are meant to benefit by it. The protection extends in particular to the Islamic marriage rights of unilateral divorce ("talak") and polygamy.

The law is probably one of the most written-about pieces of modem Indonesian legislation. 22 These publications are practically all favourable. Still, there has been veiled criticism in certain Indonesian quarters against it. 23 This criticism may be warranted. It is not evident in particular that the three innovations mentioned above have worked out as intended by the legislator. This can be briefly illustrated as follows.

To start with, it is not evident that the aim of legal unification has been achieved. Indeed, it is questionable whether the religious basis of marriage does allow for unification in a multireligious state such as Indonesia.24 After the enactment of the Marriage Law, legislation has in fact started to differentiate between Muslims and non-Muslims, with separate legislation applying to each group. Differentiation has also been called into existence to distinguish between Muslim civil servants and persons who are not civil servants in marriage and divorce, as will become evident later in this paper. All these categories of

Peradilan, 1989, V/50, p. 150-152, himself a Supreme Court judge, which is explicitly critical both of the reasoning and of the outcome.

21 N. Soewondo, Law and status of women in Indonesia, Columbia Human Rights Law Review, 1976, p. 123-140, and The Indonesian Marriage Law and its implementing regulation, Archipel 13, 1977, p. 283-284. M.U. Subadio, Perjuangan untuk mencapai undang-undang perkawinan, Jakarta: Idayu, 1981. See generally $C$. Vreede-de Stuers, A propos du RUU, histoire d'une legislation matrimoniale, Archipel 8, 1974, p. 21-30.

22 Indonesian publications list hundreds of contributions, including two Ph.D. theses in recent years (S. Prawirohamidjojo, Pluralisme dalam perundang-undang Perkawinan di Indonesia, Surabaya: Airlangga University Press, 1986, and D.T. Djarot Surianegara, La pluralité des statuts personels dans le droit Indonésien (conflits intemes et conflits intemationaux), Paris: Paris I - PanthéonsSorbonne, 1986). Our bibliographical data on the subject indicate that the number of publications on the subject in a non-Indonesian language approach fifty.

23 The continuing publications on the Dutch civil marriage law most certainly are an indication of this. S. Hartono, Akibat hukum dari perkawinan menurut sistem Burgerlijk Wetboek, Yogyakarta: Fakultas UGM, 1983.

24 An essential problem is what one really means by unification. In a limited sense unification could be taken to mean that all citizens be govemed by one law. In this sense a unified law really is a technical matter. In a wider sense it could be taken to indicate that they must have equal rights and duties by means of a single law. In this sense a unified law is a matter of justice and faimess. In view of the colonial history, when legal plurality undeniably resulted in an inequality of rights, it is not unreasonable to assume that it is the latter view that lies behind the unification drive in Indonesia. It is in this latter sense then that we use the term unification. 
Indonesian citizens have different rights in marriage. It appears then that the law promotes plurality, be it based on creed and hence in another form than that left behind by the colonial govemment. 25

Regarding the prime reference point of religion, the Marriage Law has created confusion as to which religious prescripts should apply and which should not. Should on the basis of art. 2 religious prescripts apply in toto? The question is not dissimilar to the one asked in colonial times: Should religious prescripts apply to all Muslims under all circumstances or only inasfar as accepted by state legislation? Not a few respected scholars have explicitly argued in favour of the former interpretation of art. 2.26 Yet this cannot have been the idea of the govemment. Indeed, the law itself states unequivocally that religious prescripts only apply insofar as not in disaccord with the law.27 Still, by incorporating this article, the Indonesian government has shouldered a political liability and seen itself forced to justify at every twist and turn why state laws apply instead of diverging religious prescripts. 28 Indeed, the tide may be running against it. The role of religion has become so pronounced over the years, that the government has seen itself forced to all appearances to forbid marriages that are in disaccord with religion. 29 Recent developments in Indonesian law

25 This has also been pointed out by prominent Indonesian legal scholars, such as S. Gautama, Mahkamah Agung dan keanekaragaman hukum perdata, Hukum dan Pembangunan 1, 1987, p. 62 68. It is not clear thereby to what extent the variety in Indonesian society tolerates a govemment imposed single set of norms. There are indications that even in those cases where the law is unified, legal reality forces in plurality through the courts (S. Pompe and C. de Waay, The end of "Hukum Antargolongan"?, BKI, 1989, 145/II-III).

26 Hazairin, s. footnote 8; H.S. Syahar, Undang-undang perkawinan dan masalah pelaksanaannya ditinjau dari hukum Islam, Bandung: Alumni, 1976; Soemiyati, Hukum perkavinan Islam dan undang-undang perkawinan, Yogyakarta: Liberty, 1982; M.I. Ramulyo, Tinjauan beberapa pasal undang-undang nomor 1 tahun 1974 dari segi hukum perkawinan Islam, Bandung: Alumni, 1986; Asmin, Status perkawinan antar agama ditinjau dari undang-undang perkawinan no. 1/1974, Jakarta: Dian Rakyat, 1986.

27 Elucidation to art. 2 (Tambahan Lembaran Negara 1974, p. 4)

28 Thus, the new law on religious courts which was being debated at the Indonesian parliament at the time of writing gives greater autonomy to the religious courts by freeing them from the nominal supervision of the civil courts whilst at the same time extending their jurisdiction to all inheritance cases between Muslims govemed by Islamic law (Thalib, s. footnote 18). This law has amended art. 236a of the colonial law procedure (Herziene Indonesische Reglement) to the effect that the religious court now may assist in the inheritance procedure even in the absence of a dispute (art. 107 (2)).

29 Hooker has argued that the Marriage Law has incorporated Islam in the Indonesian legal system, and that this allows the state to control it (Hooker, s. footnote 9, p. 273). It is possible that recent developments are indicative of an opposite effect, namely that the present appeal of Islam in Indonesian society (which may have political reasons) necessarily gives it an ever greater political weight in the Indonesian govemment. Thus, at least for the moment, the view of Snouck that Islam would inevitably grow is vindicated. This view, on which Lev already remarked in 1972, seems to be very much alive today (Lev, s. footnote 3, p. 15, 106). 
specifically indicate that Muslim women cannot marry non-Muslim men and retain their religion at the same time. 30 This can hardly have been the intention of the Pancasila state.31

30 S. Pompe, Mixed marriages in Indonesia; some comments on the law and the literature, BKI, 1988, 144/II-III, p. 259-275, and A short note on some recent developments with regard to mixed marriages in Indonesia, BKI (forthcoming 1990). Developments are not without problems and constitute a possible indication of the confusion that exists in government circles on this matter. At first, it is reported by authoritative authors that civil (i.e. non-religious) marriages have been possible after 1974, whatever the law (J.S. Katz and R.S. Katz, Legislating social change in a developing country: the Indonesian Marriage Law revisited, American Joumal of Comparative Law 26, 1978, p. 309-320). Jurisprudence from 1975 is cited to support this. This allows partners with different religions to marry. Acquaintances of the authors have concluded civil marriages as recently as 1986. In 1975 the Indonesian Supreme Court instructed the lower courts to the effect that the above-mentioned Regulation on Mixed Marriages still applied inasmuch as in accord with the Marriage Law (nr. MA/Pemb. 0807 dated 20 August 1975. See also the similar Decision of the Minister of the Interior no. 221 a/1975 of 1 October 1975). Marriages between partners of different religions were allowed therefore. In 1979 and in some later cases the Mahkamah Agung gave effect to its own instruction and held that the Regulation on Mixed Marriages applied to these cases of marriages between partners of different beliefs (nr. 1650K/Sip/1974 dated 13 November 1979 in Yurisprudensi Indonesia 1980 (I), p. 111; also nr. 32K/AG/1983 dated 22 August 1983 in: ZD. Basuki, Perkawinan antar agama dewasa ini di Indonesia, ditin jau dari segi hukum antar tata hukum, Hukum dan Pembangunan 17-3, 1987, p. 235-243). In 1986 the District Court of Central Jakarta decided however, that a marriage between a Muslim girl and a non-Muslim boy would in effect be impossible (nr. 382/PDT/1986/PN.JKT.PST in Varia Peradilan IV/45, 1989). The reason advanced by the court was that such a marriage could not be registered at the Muslim Marriage Bureau (Kantor Urusan Agama - KUA) as it was in disaccord with Islam. Nor could it be registered at the Civil Registry (Catanan Sipil) for non-Muslim marriages as the girl was a Muslim. On January 12,1987, it was decided during a meeting between the ministers of the Interor, Justice and Religious Affairs that civil marriages would be impossible (Kompas 12 April 1987). The Mahkamah Agung case of January 1989 cited in footnote 19, overtumed the 1986 case of Central Jakarta District Court, but with entirely innovative reasoning. It says that if a request for marriage between a Muslim girl and a non-Muslim boy is being presented at the Civil Registry after being rejected at the KUA, the girl must be taken to have abandoned her religion and that consequently there is no objection in law to concluding the marriage at the civil registry. This latest situation then seems to be that one must choose between partner and belief. Whilst personal communications to one of the authors by lawyers in the highest judicial circles in Indonesia have indicated that this judgment was actually meant as a direct instruction to the Civil Registries to allow mixed marriages, it appears that these still do not comply. In fact, one of the Vice-Presidents of the Indonesian Supreme Court is reported to have complained in the fall of 1989 that his daughter was not able to conclude her (mixed) marriage even after the above-mentioned judgment of the court. As pointed out earlier, the judgment has been publicly criticized from within the Supreme Court in a case-note by $B$. Siregar, s. footnote 20 . The law then appears to be still very much unsettled on this point.

31 It is said in Indonesian legal circles, that a draft Marriage Law including art. 2 had been refused consent when presented to President Sukamo in the early nineteen-sixties. According to this story, President Sukarno argued that the potentially polarising effect of marriage based on religion necessitated maintaining civil marriage as a basis of marriage in Indonesia. In private communications to one of the authors, Indonesian scholars and notaries have indicated furthermore that the 1989 
Of the three fundamental innovations and principal aims of the government in enacting this law, there is good reason to claim that under the influence of Islam in particular two have not quite worked out the way they were intended.

Yet, it is the third innovation that we propose to consider here today: that of the legal protection of women in Islamic marriage.

\section{The Rights of Women According to Islamic Religious Prescripts and the Law: Polygamy and Unilateral Divorce32}

\section{Islamic Religious Prescripts}

In this short review we will confine ourselves to the general outlines.

Islam allows polygamy, although it is generally regarded as morally abhorrent. A man may marry four wives (Koran IV, 3).33 As far as the marriage ceremony is concerned, a number of conditions must be fulfilled. These relate in part to the persons in marriage and in part to the marriage procedure. It goes beyond the scope of this paper to delve into this too deeply. 34 Yet the conditions for a polygamous marriage according to Islamic religious prescripts are not many. Witnesses are required and equal treatment of all wives is prescribed. 35 These have also been adopted as a requirement in the Indonesian legislation.

Islamic prescripts on unilateral divorce are rather lenient. There is no limitation on the grounds of divorce. The procedure is very simple: the only requirement in the Shafi'ite

Supreme Court judgment may not be sound dogmatically. It entails that a party may have to abandon his religion to marry but need not acquire another religion. The scholars and notaries have suggested that this infringes upon the requirements of good morals or public order in the Penal Code. Pompe (s. the forthooming article, footnote 30) has argued that this judgment may be in conflict with the equal rights between men and women and with the freedom of religion as vested in the Indonesian Constitution (art. 29 (2)) as well as in the Universal Declaration of Human Rights (arts. 16 (1) and 18).

32 In this article the Marriage Law 1974 will henceforth be abbreviated as Marr. Law.; the Govemment Regulation nr. 9/1975 giving effect to this law in the field of polygamy and unilateral divorce will be abbreviated as Gov. Reg. 9/1975, whilst the Govemment Regulation nr. 10/1983 applying specifically to marriage law between civil servants will be abbreviated as Gov. Reg. 10/1983. The new law on the religious courts of 1989 will be abbreviated as Rel. Courts Law.

33 This is at least the way in which this Sura is traditionally read. For other visions see $Y$. Linant de Bellefonds, Traité de Droit Musulman Comparé. Livre II: Le Mariage, Paris/La Haye: Mouton \& Co, 1965, p. 134-135.

34 Regarding the requiments on intra-religious marriages we refer to footnote 15.

35 As is now generally known, this crucial requirement has become the main argument for some countries in the Muslim world, such as Tunesia, to forbid polygamy altogether. 
school to which Indonesia belongs is that a wife may not be divorced unilaterally during the "iddah" period and that the divorce concerns only her.36 No witnesses are required in any of the sunnite law schools.

All this is greatly in contrast to the Indonesian marriage legislation.

\section{Indonesian Low}

It is often said that the Indonesian marriage legislation aims at leaving the marriage rights which are given to the husband by Islam intact. It is argued that the tactic that has been followed by the legislator is that of an encumbering and discouraging procedure which must be followed on the pain of nullity by those who want to avail themselves of these rights. Close inspection will reveal however, that whilst the rights of polygamy and unilateral divorce still exist in Indonesian state law, these are on the whole more limited when compared to Islamic religious prescripts. 37

\section{a. Polygamy}

The Marriage Law is based on the principle that marriage must be monogamous (art. 3 (1) Marr. Law). Polygamy is only allowed by means of a specific procedure and under exceptional circumstances which are exhaustively listed in the law (art. 3 (2) Marr. Law).

As regards the procedure, a request must be submitted in writing to the competent judge, being the Religious Court (art. 4 (1) Marr. Law, art. 40 Gov. Reg.). In principle, no polygamous marriage may be concluded without his consent (art. 4 (1) Marr. Law, art. 40 Gov. Reg. 9/1975).

The judge is not free to decide upon a request before him as he pleases. The law gives a limitative list of conditions allowing consent. Otherwise consent must be denied. These conditions can be divided into two groups, which presumably must both be fulfilled.

The first appertain to the physical state of the wife with whom the applicant is married already. They are threefold (art. 4 (2) Marr. Law, art. 41 Gov. Reg. 9/1975):

- the wife cannot filfill her duty as a wife;

36 Juynboll, Th. W., Handleiding tot de kennis van de Mohammedaansche Wet volgens de leer der Sjafi'itische School. Leiden: Brill, 1925, p. 203; Linant de Bellefonds (s. footnote 33), 321.

37 Examples of cases in which Islam appears to be stricter than Indonesian legislation are intrareligious marriages, kinship rules and the "iddah" period after divorce. 
- the wife has a permanent physical handicap or an incurable illness;

- the wife cannot bear any children.

It must be taken that the wife must fail in one and not all of these categories. 38

The second group of conditions bears on some additional guarantees that have to be given. The first and most important condition in this category is no doubt that the first wife must agree explicitly to the polygamous marriage of her husband. This agreement must be either in writing or be spoken out loud before the court (art. 3 (2) \& 5 (1) Marr. Law, art. 42 Gov. Reg. 9/1975). The second condition is that the husband must prove by means of bank accounts and the like that he will be able to support all his wives financially. The third and final condition is that he must promise to treat his wives on equal terms. 39 It must be taken that the conditions in this second group must be fulfilled cumulatively. 40

Regarding civil servants, including ministers of state, specific conditions apply. 41 The reason for this specific additional treatment according to the law is that "the civil servant has the duty to be an example to his subordinates and a model of a good citizen in society, which also goes for his family life".42 Polygamous marriages between civil servants are completely forbidden (art. 4 (2) Gov. Reg. 10/1983). If a civil servant wants to conclude a polygamous marriage with someone who is not a civil servant, permission must first be sought and obtained from the hierarchical superior, who has to reply within three months after being requested (art. $4 \& 16$ Gov. Reg. 10/1983). 43 This permission must be obtained within six months fo the request being submitted to the judge. 44

38 Circular Letter of the Head of the Coordinating Board for Civil Servants nr. 08/SE/1983 dated 26 April 1983, heading IV sub a.

39 It remains to be established whether the promise required by the Indonesian legislation can be enforced in the courts.

40 Circular Letter of the Head of the Coordinating Board for Civil Servants nr. 08/SE/1983 dated 26 April 1983, heading IV sub b.

41 These conditions are regulated in Govemment Regulation nr. 10/1983 which has been effected in greater detail by the Circular Letter of the Head of the Coordinating Board for Civil Servants (BAKN) nr. 08/SE/1983 dated 26 April 1983. Similar regulations apply to other branches of the public service such as the Armed Forces (Decree of the Minister of Def ence and the Chief of Staff of the Anned Forces nr. Kep/01///1980 dated 3 January 1980), the police (Technical Decree of the Head of Police nr. POL.JUKNIS/01/II/1981 dated 31 March 1981) and the public prosecution (Regulation of the Prosecutor General nr. PER.001/JA/5/1982 dated 19 May 1982).

42 Introductory consideration b. to Government Regulation 10/1983. Civil servants are thus explicitly forbidden on the pain of administrative sanctions to live together as a couple outside the legal marriage bond ("kumpul kebo") and may be instructed to that effect after a formal investigation (Circular Letter of the Head of the Coordinating Board for Civil Servants (BAKN) nr. 08/SE/1983 sub VII dated 26 April 1983).

43 Circular Letter of the Head of the Coordinating Board for Civil Servants (BAKN) nr. 08/SE/1983 at IV sub 6 dated 26 April 1983.

44 Circular Letter of the Supreme Court nr. MA/Pemb/2968/84 dated 17 April 1984. 
What happens if a polygamous marriage is concluded without judical consent having been obtained? There are two possivilities here.

First, of a polygamous marriage is concluded after the judge has decided unfavourably upon a request submitted to that effect, the marriage must be deemed to be null and void even though it may be in accord with Islamic religious prescripts. The parties may be prosecuted for having committed a criminal offence under the Indonesian Penal Code (art. 279 Indon. Penal Code). 45

Second, if they have concluded a polygamous marriage without requesting judicial consent at all, the polygamous marriage is regarded as valid provided the other legal stipulations have been observed. What this really means is that the marriage is valid of the judge would have given his consent if he had been asked (art. 45 jo. 40 Gov. Reg. 9/1975).46

Jurisprudence appears to follow the law quite closely. There are a number of well-known examples that can be found in publications on the subject. 47 Best known amongst these is perhaps the Malang case in which the man motivated his request to the judge with the argument that he had an extraordinary sexual appetite. The request was dismissed. In another well-known case, the man founded his request on the fact that he wanted children. It was dismissed after it had been established that he had nine children already. Less well known but legally perhaps more interesting was the Lombok case in which parties concluded a polygamous marriage without putting a request before the judge. The marriage was found to be null and void. The fact that it had been concluded in accordance with Islamic religious prescripts did not alter that judgment. On the contrary, the "wali" who had concluded the marriage was considered to be an accomplice to the crime and condemned to twenty days imprisonment with costs. Finally, the consent of the first wife was put to the test in a Supreme Court case of 1980. No consent having been given in this case, the polygamous marriage was found to be null and void, whereas the parties were condemned to one month imprisonment. 48

45 Circular Letter of the Supreme Court nr. MA/Pemb/0156/77 dated 25 February 1975. See recently D.D. Suriawinata, "Kawin Agama" merupakan unsur "kawim lagi" yang diminta oleh pasal 9 undang-undang no. 1 tahun 1974 yo. pasal 279 KUHPidana, Varia Peradilan 1989, IV/45, p. 135 137.

46 Circular Letter Indonesian Supreme Court nr. MA/Pemb./0156/77 dated 25 February 1975. There is evidence that the penalty of art. 45 Gov. Reg. 9/1975 to the amount of Rp. 7.500.- is considered to be too low to have the discouraging effect intended by the legislature. There is jurisprudence adopting the much more rigourous penalty of art. 279 Indon. Penal Code for this second category of offences (Supreme Court Decision nr. 381K/Kr/1979 dated 27 February 1980). See also Prawirohamidjojo, footnote 22 .

47 notably $K a t z$ \& $K a t z$ (s. footnote 30$), 311$.

48 Supreme Court Decision 17 April 1980, Nr. 435K/kr/1979, Yurisprudensi Indonesia 1981 (II), p. 28. 


\section{b. Unilateral Divorce}

According to the Marriage Law a marriage can only be dissolved by death of one of the partners or by a decision of the judge (art. 39 (1) Marr. Law).

The precise meaning of "decision" differs in a Muslim and non-Muslim divorce procedure, as does the role of the judge. A marriage between non-Muslims is legally dissolved by the judge and takes effect upon registration in the civil registry. $49 \mathrm{~A}$ marriage between Muslims takes effect upon judgment. In this case the judgment may follow upon a request for unilateral divorce by the husband ("permohonan"; art. 14-18 Gov. Reg. 9/1975, art. 66 Rel. Courts Law) or upon a writ of summons by the wife ("gugatan"; art. 20 Gov. Reg. 9/1975, art. 73 Rel. Courts Law). A judgment following a unilateral divorce declaration by the husband is an affirmation of an existing situation ("penetapan", art. 70 Rel. Courts Law). The law says that the judge "witnesses" the divorce (art. 16 \& 17 Gov. Reg. 9/1975, art. 70(3) Rel. Courts Law). Divorce has effect upon the pronouncement of the unilateral divorce formula by the husband (art. 18 Gov. Reg. 9/1975, art. 70 (1) jo. (3) Rel. Courts Law). 50

The role of the judge in unilateral divorce cases is, however, not supposed to be that of a passive bystander. The Marriage Law imposes upon him first the duty to try and reconciliate the partners (art. 39 (1) Marr. Law, art. 82 Rel. Courts Law). According to the new law on the religious courts, this is done in a session between the judge and both spouses (art. 82 (2)) with no other parties (such as counsel) attending. Such reconciliation attempts

49 The colonial regulation for the civil registry originally only applied to the European and Foreign Orientals population groups as well as to certain groups of Indonesians, such as most notably Christian Indonesians (S. 1920-751 jo. S. 1927-564). From 1966 all Indonesians were subjected to this regulation however (Instruksi Presidium Kabinet nr. 31/U/IN/12/1966). Gouwgioksiong, De verhouding tussen intemationaal privaatrecht en intergentiel recht in Indonesië, NTIR XIV, 1968, p. 345-366.

50 The terms "permohonan" and "gugatan" are difficult to translate into English. They indicate different types of procedures that very possibly draw back to the Dutch "verzoekschrift" and "dagvaarding" respectively. The rule of the thumb in Dutch law is that contentious procedures should start with a "dagvaarding" whereas so-called voluntary procedures commence with a "verzoekschrift". The former ends in a judical decision deciding the conflict and establishing a new legal relationship ("vonnis"), the latter merely establishes a legal fact that conceptually speaking already was there ("beschikking"). Indonesian law does not appear to follow a different line. The "beschikking" can best translated with "penetapan" (which is the way in which Indonesian experts translate the term: A. Boediarto, Perkavinan beda agama. Rechtsvacuum, Varia Peradilan 45, 1989, p. 73-77), the "vonnis" with a "keputusan". Dogmatically the Indonesian procedure is quite sound, therefore. Unilateral divorce is not a contentious procedure, since it is legally irrelevant whether or not the wife agrees. It should therefore commence with a "permohonan". Legal effect of the divorce resorting not with the decision of the judge, but with the rejection of the wife before him, judgment should be by "penetapan". 
must be done at all sessions and at all instances (official elucidation art. 82 (1) Rel. Courts Law). There must be at least two court sessions before a divorce may be granted. $51 \mathrm{He}$ must check thereby whether the divorce is in accordance with the law.

The law states quite clearly that a divorce must answer specific conditions. As regards the procedure, a request must be submitted to the court in writing (art. 14 Gov. Reg. 5/1975). This request must be motivated. Only on the grounds of certain motivation may the divorce procedure proceed. These are: adultery, alcoholism, drug addiction, compulsive gambling, absence of two or mor years, emprisonment of five years, incurable illness or permanent physical handicap which prevent the fulfillment of matrimonial duties and finally, fundamental disaccord. If the husband is a civil servant, permission of his superior is essential on the pain of immediate dismissal (art. $3 \& 16$ Gov. Reg. 10/1983). This permission must be given within three months. 52 This permission must be obtained within six months of the request being submitted to the judge. 53

Jurisprudence follows the law quite closely again. There is steady jurisprudence stating that if any of the above stipulations is infringed upon, the divorce must be deemed to be null and void. Thus any unilateral divorce outside the court is invalid according to the Supreme Court, irrespective of the possibility of its validy according to Muslim prescripts. 54 The reasons given in support of a unilateral divorce must be in accord with those mentioned in the law. Thus, a unilateral divorce on the grounds that the wife used magic against the husband was refused by the Supreme Court. 55

\section{Some Comments about Effectiveness}

As far as the protection of women in marriage is concemed, it is clear that the Indenesian legislator has opted for procedural obstacles and a certain material limitation on the rights of polygamy and unilateral divorce. These rights themselves have been maintained. The argument presumably is that God-given rights cannot be abolished by man-made laws. This

51 Circular Letter of the Supreme Court nr. MA/Pemb/7464/85 dated 19 August 1985. See also $I$. Campbell, Family law and inheritance law in West Java - change and continuity in the period from 1900 to the present day. University of Sydney (unpublished MA Thesis), 1988, p. 46.

52 Circular Letter of the Head of the Coordinating Board for Civil Servants (BAKN) nr. 08/SE/1983 at III sub 8 dated 26 April 1983.

53 Circular Letter of the Supreme Court nr. MA/Pemb/2968/84 dated 17 April 1984.

54 Supreme Court decision nr. 1335K/Pid/1985 dated 30 September 1987 in Varia Peradilan 1988 III/28, p. 55 following nr. 04K/AG/1979 dated 22 October 1979 and nr. 09.K/Ag/83 dated 28 June 1983.

55 Supreme Court decision nr. 024/K/AG/1979 dated 22 October 1979 Yurisprudensi Indonesia 1980 (I), p. 142-147. 
is only one way of looking at the "sharia" of course, which may be too facile. ${ }^{56}$ As the case of Tunesia indicates, God-given rules can also be read to the effect that they abrogate the rights of polygamy and unilateral divorce (Al-Nowaihi 1977).

The protection for women in marriage is not without its problems on a theoretical level. Thus, the motivation for divorce on the basis of fundamental disaccord has been adopted from art. 209 of the Dutch colonial Civil Code ("onheelbare tweespalt"). Whilst in colonial times Indonesians were generally not subjected to book I of the colonial Civil Code containing this article, this motivation had already been admitted in Supreme Court jurisprudence before the Marriage Law of 1974 (nr. 500K/Sip/1971 dated 26 November 1971). This Motivation for divorce is rather vague and is difficult to disprove. As a result it is precisely this motivation that has been advanced most frequently as a motivation for unilateral divorce. The problem has been officially recognized in that judges have been admonished officially by the Supreme Court to make an active investigation into the causes of this disaccord and not accept it at face value (Circular Letter nr. MA/Pemb./0789/81 dated 6 July 1981). This has meant amongst others that witnesses must be heard as has been established jurisprudentially also (nr. MA 50K/AG/1980 dated 3 June 1981 and nr. $08 \mathrm{~K} / \mathrm{AG} / 1981$ dated 24 March 1982). This judicial intervention has been confirmed by the legislator in art. 76 Religious Courts Law, which provides specifically for the calling of witnesses in the case of this ground of divorce being advanced.

Yet some protection there evidently is in the law. The more important question is whether this protection envisaged by the legislator is reflected in practice. It is evident that there are problems here, both outside the courts and inside them. It goes too far to look at them in detail, yet the following points can be mentioned here. 57

\section{The Law is Improperly Applied in the Religious Courts}

In the end little is known about the practical workings of the Marriage Law. The effectiveness of the Marriage Law has never been looked at in depth. There are indications that the law has driven polygamy and unilateral divorce underground and beyond the reach of government statistics (Campbell 1988). Several studies have pointed out that the Marriage Law is inadequately applied in religious courts. These suggest that judicial fiat for polygamous marriages or unilateral divorce are granted without regard to the Marriage Law and

56 We thank Mr. Buskens for pointing this out to us.

57 One of the points that will not be reviewed but which merits a brief mention is that on the basis of the statistics reviewed hereafter an excessive number of unilateral divorce cases are advanced on the ground of "irreparable discord" between the spouses. This ground is hard to disprove. 
sometimes in flagrant conflict with it. ${ }^{58}$ One of the authors has pointed out on the basis of published jurisprudence that social reality might compel judges to agree to divorces concluded outside court. 59 These are all troubling points, which cry out for further systematic research in the field. 60

\section{The Religious Courts Generally View the Law Differently from the Supreme Court}

The studies mentioned above support the idea that there are important differences in the way the marriage legislation as a whole is viewed by the first and second instance religious courts on the one hand and by the Supreme Court on the other.61 It appears from the jurisprudence that the courts of first and second instance are more inclined towards interpreting this legislation in the direction of Islamic religious prescripts than the Supreme Court which is more secularly disposed.62 Indeed, the lower courts sometimes decide cases

58 Poerbatin, D. H., Penerapan pasal 3, 4, 5 UU no. 1 tahun 1974 di Pengadilan Agama Jakarta Pusat, Hukum dan Pembangunan XV/5, 1985, p. 481-485; Rochijanto, H., Pelaksanaan pasal 39-41 /UU no. 1 tahun 1974) beserta peraturan pelaksanaannya (pasal 14-36 pp 9 tahun 1975) pada Pengadilan Agama Jakarta Utara tahun 1980-1982, Hukum dan Pembangunan XV/5, 1985, p. 474-480; Campbell (s. footnote 51).

59 Pompe, $S$, De invloed van het adatrecht bij de toepassing van het strafrecht in Indonesië, BKI 143/IV, 1987, p. 499-506.

60 It should be added in this context that very little attention has been paid to the religious offices (KUA) which handle day-to-day marital affairs at a local level. As suggested by $H$. Nakamura, Divorce in Java, Yogyakarta: Gadjah Mada University Press, 1983, it may be that these offices are much more influential in day-to-day marital matters than the religious courts. Whilst Nakamura limits her analysis to the cases which are settled peacefully through intervention of the KUA (and therefore do not fall within the competence of the court as there is no conflict), it is not unlikely that the KUA settles a good deal more and that certain - and quite possible a wide range of - functions of the religious courts (such as unopposed divorces) are actually performed by the KUA. These could actually show up in official govemment reports as court work, whereas in fact the KUA has done all the spadework. As a result the relationship between the KUA and the religious courts merits closer study in the field.

61 Lev (footnote 3) has described at some length the struggle for increased independence and authority of the religious courts from the civil courts in particular. The Marriage Law has assisted the courts in this struggle, as pointed out by Hooker (footnote 9). It is now evident, however, that far from increasing their dependency from the civil courts, as suggested by the latter author, the religious courts are more autonomous if anything. Hooker refers to the fact that formally speaking on the basis of the colonial statute goveming religious courts until 1989 the civil courts must still validate a judgment from these courts. Yet, long before 1989 this validation appears to have become a rubber stamp and the new law on the religious courts of 1989 abolishes it altogether. As indicated above, the authority of the religious courts in the field of inheritance has not only been confirmed but increased by means of art. 236a H.I.R. All this points towards an increasing independence of the religious courts.

62 The review of the Law in paragraph 3 may be deceptive in that it states the law as it is supposed to stand according to the formal sources of law, including court decisions preferably at the highest 
in flagrant contravention with the law or jurisprudence. Besides material analysis of the decisions, a further indication of this difference regardes the form of the decisions in which the supreme Court hardly ever cites the Koran, whereas the religious courts of first and second instance never seem to miss an opportunity for doing so. That this difference in viewing the law may have more deeply rooted causes is supported by the fact that the religious courts of first and second instance fall within the administrative competence of the Ministry of Religious Affairs, whereas the Supreme Court is a separate administrative unit and a high organ of state. 63 Judges in the religious courts also appear to have had a more religious than academic, legal or political background than is the case in the Supreme Court.64 This, to be sure, is based on a rather cursory glance at the subject which requires closer study for definite confirmation. Yet it is not unlikely that these factors contribute to a reduced protection against unilateral divorce and polygamy in the lower courts.

\section{Statistics: The Courts are Understaffed and Overworked and notably Unilateral Divorce Remains a Problem}

There is general agreement in publications on the subject that according to the government statistics polygamy and unilateral divorce have decreased dramatically nationwide after the enactment of the Marriage Law. 65 It has been suggested that the aim of the legislator to create administrative and financial obstacles has there fore worked out as intended. Yet the

level. Lower courts are supposed to follow to Supreme Court decidions, but they may not do so as indicated by the most recent case on mixed marriages reviewed in footnote 29 . It should be emphasized in this context that the number of marriage cases actually going up for appeal at the highest level is completely negligeable compared with the number of first instance cases.

63 Constitution 1945 art. 24, Ketetapan MPR III/MPR/1978 on the High Organs of State.

$64 \operatorname{Lev}$ (s. footnote 3, p. 102) has pointed out the poor quality of the judges in the religious courts as a major problem in this development in his time. The govemment statists on West Java indicate that this problem has not yet been solved. These statistics give the education and professions of judges that are not permanently attached to the courts, not of those, unfortunately, that are permanently so attached. Inasfar as listed, of the 104 judges only one has had an academic education at a state university, 6 at a religious institute of higher education (IAIN). The others have no education beyond secondary school, though many had done additional courses in Islamic theology. No other professions were listed than that of teacher in Islam. All this indicates that judges will be by and large more susceptible to a traditional interpretation of the "sharia" conducive to polygamy and unilateral divorce. There are developments indicating a shift in this respect. One of those is the cooperation program concluded between Indonesia and the Netherlands, whereby Indonesian Islamic scholars will be trained in research techniques.

65 Katz \& Katz (s. footnote 30); Prawirohamidjojo (s. footnote 22); Campbell (s. footnote 51). 
statistical data for the vrious regions that have been published by the government in ever greater numbers over the past few years do not appear to unequivocally support this view. 66

Concentrating on the province of West Java, it appears from statistics over the years 1981/2 that polygamy cases are relatively small in number. In those years the western districts of the province lists polygamy cases in single figures (Pandeglang 6, Rangkasbitung 6), with the rather religious area of Banten (in the district of Serang) being on the high side with 17 polygamous marriages. The figures for the westem districts are generally higher but still not very sizeable when related to the total number of inhabitants (Cirebon 76, Indramayu 53, Tasikmalaya 108). 67

The figures for unilateral divorce are quite different from those on polygamy. Though the statistics are somewhat confusing on this point, one can deduce that the number of unilateral divorce petitions handled by the court are much more sizeable. In the Serang district 327 unilateral divorces were dealt with in 1982/3, in Pandeglang 90 and in Rangkasbitung 146. The eastern provinces list much grater number of unilateral divorce cases: Tasikmalaya 3.625, Cirebon 5.324 and Indramayu a stupendous 10.488 divorce cases. This suggests that unilateral divorce is still very much alive in these districts. 68

The practical problems of handling such a high number of cases can hardly be overestimated.69 Indramayu can serve as an example here. According to the official statistics, the religious court of Indramayu only has four regular judges in session, with seven judges helping out on a temporary basis. Taking only the divorce cases and sitting in three-judge chambers, they must decide more than 200 cases a week. If two sessions are minimally held before the court as required by the Supreme Court, this means at least 400 sessions a week. The court itself reports in the official statistics that in all, it has to judge 500 cases a week. With such a heavy work load, there can be little opportunity for the judges to deal with unilateral divorce cases with the thoroughness prescribed by the detailed marriage legisla-

66 Statistics are not without their difficulties generally, the ones reviewed notably so. Their authority lies not in their academic worth, but in the fact that these are the official statistics through which, presumably, the Indonesian govemment monitors the effect of its legislative efforts in this field.

67 The number of inhabitants of these districts as listed is: Serang 1.1 Million, Pandeglang 638.000, Rangkasbitung 684.000, Cirebon 1.5 million, Indramayu 1.2 million, Tasikamalya 1.5 million.

68 These statistics may not be entirely reliable, but the Indramayu figure need not be far of the mark either. It has long been recognized as a rather extreme case and Campbell reports special research being carried out in this respect by Dr. L. Rasjidi (Campbell, s. footnote 51, p. 45). We have been told that cases are known in which a lady from Indramayu had married 21 times.

69 See our earlier comment on the possible assisting role of the KUA, however. 
tion in this field. ${ }^{70}$ This is supported in fact not only by a number of publications mentioned hereafter, but the statistical data indicate that most divorce actions are granted. Here again there is a difference between the western and the eastern provinces: in the first almost a quarter is rejected, whereas in the second case the number of rejected divorces is only $4 \%$.

These statistics therefore do not prove that the Marriage Law has succeeded in limiting unilateral divorce.

\section{Conclusion}

The Marriage Law of 1974 has been generally regarded as an impressive feat of legislative reform and social engineering in Indonesia. This reputation may be warranted to some extent, but as time passes a number of problems have gradually surfaced. This article does not claim to have studied these problems exhaustively, but to have pointed them out in the hope that furter research, notably in Indonesia itself, will be channelled in their direction.

Of what in our view can be regarded as the three major points of reform of the Marriage Law, attention is directed in this article towards the protection of women in Muslim marriages, notably in respect of polygamy and unilateral divorce. In view of the history of the Marriage Law, it must be taken to have been the aim of the Indonesian legislator to give women in Muslim marriages better protection in respect of polygamy and unilateral divorce. This has not been effected by excluding the religious rights of polygamy and unilateral divorce altogether, as would have been possible and has in fact been done in countries such as Tunesia and Turkey. Instead, these rights have been hedged in rather by cumbersome and difficult administrative procedures the purpose of which at least to some extent appears to be to limit the possibility of arbitrary use of these rights as much as possible.

There are indications in our view that this approach suffers from a number of practical weaknesses the full extent of which remains to be determined, but which on the face of them cast doubt upon the effectiveness of this protection. These practical weaknesses are threefold and closely interrelated: first, the religious courts appear to apply the marriage law improperly; second, the religious courts view the marriage law quite differently from the Supreme Court; third, the religious courts are understaffed and overworked. On the basis of the sources available, notably jurisprudence, government statistics and data from nationale huwelijksrecht, Recht van de Islam 6, 1988, p. 9-23. 
the field, these weaknesses have affected the rights of women, perhaps severely. Unilateral divorce in particular appears to continue unabated; one of the effects of the Marriage Law has been to help push it beyond the reach of the government statistics. These indications must be substantiated by further research in the field. 71

71 After completion of this article, the publication by $M$. Camnack, Islamic law in Indonesia's New Order, Intemational and Comparative Law Quarterly 38, 1989, p. 53-73, was brought to our attention. It could not be included in this article. Interestingly enough, the line of reasoning and conclusions of Cammack to a large extent support our views as expressed in this article. 
of the payment of one lump sum on the retirement of other public servants and private employees. Unlike the Pension Scheme, the Social Security Scheme is a contributory system under which both employers and employees contribute to a Fund; and it is a mere compulsory saving system. Members of the Scheme become entitled to receive sufficient benefits only after they made contributions over a long period of years. However, even then the value of the amount paid on retirement is considerably diminished because of inflation. Hence the dissatisfaction with the existing system of social security.

In view of this, the labour force urged the Govemment to convert the social security system into a pension scheme available for everybody. A new Pension Scheme was then drafted and suggested by the Social Security and National Insurance Trust to the Government. Everybody, including selfemployed persons, can become a member and contribute to the Fund. After a minimum period of 20 years a person qualifies for pension benefits. The current periodical payments of pension benefits are reviewed following changes in the general level of eaming in order to take into account the effects of inflation. Since the success of the Scheme depends to a great extent on the adoption of a sound investment programme, the existing restrictions on investments are removed.

It is expected that the new Pension Scheme will become law soon. If this will be the case, one has to wait and see how successful it will be in giving more lasting security to the elderly than was the case under the existing Social Security Scheme.

\title{
Some Comments on Recent Developments in the Indonesian Marriage Law with Particular Respect to the Rights of Women
}

\author{
By S. Pompe and J. M. Otto
}

The 1974 Marriage Law of Indonesia has been generally acclaimed as an innovative piece of legislation. In this article, however, it is argued that notably in the field of rights of women in Muslim marriages its implementation is not without problems. This article establishes that the structure of the law in these matters is to leave the rights accorded to man in Islam intact, but encumbering their use by means of procedural obstacles. In theory the result ist to give the women in Muslim marriage a better protection in law. It is then suggested that on the basis of the data presently available, the implementation ot the law is flawed in three respects. First, there appears to be a general tendency amongst the religious vourts competent in these matters to improperly apply the law. Second, the religious courts do not appear to heed Supreme Court jurisprudence. Third, the religious courts are understaffed and overworked. These factors threaten the protection accorded to women in Muslim marriage by the Marriage Law. 